\title{
THE IMPACT OF COVID-19 PANDEMIC ON NATURAL TOURISM DESTINATIONS MANAGERS IN SAMIGALUH KULON PROGO DISTRICT AS A NATURE TOURISM AREA
}

\author{
Enggrit Novialita Kelana Sari ${ }^{(1)}$, Carrolus Prima Ferri Karma ${ }^{(2)}$ \\ (1)(2) Program Studi Pendidikan Bahasa Inggris \\ Universitas Tidar \\ enggritn@gmail.com, ferriprima1@gmail.com
}

Submitted:19 June 2020 Revised: 22 October 2020

Accepted: 24 October 2020

\begin{abstract}
The ongoing coronavirus (COVID-19) flare-up as of late caused overall neurosis because of its lethal nature. The COVID-19 pandemic has a worldwide effect, even in Indonesia itself, where one of the sectors most affected is the tourism industry. One of them is in Samigaluh, which is a sub-region in the Kulon Progo Rule. This place has nearby potential, for example, common excellence that can be offered as a vacation spot and an open door for the encompassing network. This examination is to research the viewpoint of the supervisors of vacation destinations in Samigaluh to see the effect of their work career. This research uses a qualitative method. The exploration information was gathered from the supervisors of the travel industry attractions in Samigaluh, and ten inquiries were given to the chief. Thirty travel industry coordinator in Samigaluh partook in the survey. The results of this study indicate that the perspective of tourist attractions manager in Samigaluh as a whole sees the COVID-19 pandemic having a bad impact on the tourism industry in Samigaluh because job careers are threatened. Therefore, ensuring the safety of guests and staff have become a top concern of the tourism and hospitality industry stakeholders. At the same time, in order to restore business losses and to rebuild a favourable picture in the eyes of the customers, it is necessary that good marketing is undertaken and promotional campaigns, both locally and internationally.
\end{abstract}

Keywords: COVID-19, Nature Tourism, Manager, Samigaluh

\section{INTRODUCTION}

The travel industry is one of those enterprises to become Indonesia's pillar that can be a supporter of people's economy. Essentially the travel industry is a movement action so as to get fulfilment needs that are not an acknowledgment of work exercises.

As time has grown along with the development of the meaning of the travel industry, the purpose of the travel industry has also grown (Jaelani, 2017). One of the tourist destinations chosen by tourists who are tired of the hustle and bustle of urban life and the loss of value for urban conditions is rustic. In the tourism industry, this is also commonly referred to as a characteristic of the travel industry. A few regions have started to create nature as another option of tourist destinations offered to tourists, including the Kulon Progo Regime. This exploration is engaged in Samigaluh sub-area, which is at the height of 500-1000 meters above ocean level. There is numerous wonderful characteristic of the travel industry possible, for example, Sidoharjo Cascade, Nglinggo Tea Nursery, 
Enggrit Novialita Kelana Sari and Carrolus Prima Ferri Karma: The Impact of COVID-19

Pandemic on Natural Tourism Destinations Managers in Samigaluh Kulon Progo District as a Nature Tourism Area

Tritis Tea garden, Suroloyo top, Isis Hill, and so forth.

With the COVID-19 pandemic, the tourism sector in Kulon Progo, especially Samigaluh, is very limited. Almost all tourist attractions are temporarily closed until an undetermined time. This right, of course, affects the income and career of the tourism actors themselves, especially the manager of the tourist attractions.

The presence of the COVID-19 pandemic absolutely brought about abatement in a few things in the travel industry part (Mandal \& Pal, 2020). A critical diminishing was found in the number of vacation spots in Samigaluh. This likewise influences the degree of upkeep of vacation destinations by the chiefs. This study is to explore the point of view of the supervisors of vacation destinations in Samigaluh to see the effect of their work professions.

\section{LITERATURE REVIEW}

\section{Global Pandemic of COVID-19}

Coronavirus is a gathering of infections that can cause malady in creatures or people (Ramteke \& Sahu, 2020). A few sorts of coronaviruses are known to cause respiratory diseases in people running from cold hacks to increasingly genuine ones, for example, Center East Respiratory Condition (MERS) and Serious Intense Respiratory Disorder (SARS). Another sort of coronavirus has been found to cause COVID-19.

What is COVID-19? COVID-19 is an irresistible sickness brought about by a newfound sort of coronavirus (Zahra et.al, 2020). This new infection and the illness it caused was obscure before the beginning of the episode in Wuhan, China, in December 2019. COVID-19 is presently a pandemic that happens in numerous nations around the globe.

The most widely recognized side effects of COVID-19 are fever, dry hack, and weakness (Zhu et.al, 2020). Different indications that are less normal and might be experienced by certain patients incorporate a throbbing painfulness, nasal clog, cerebral pains, conjunctivitis, sore throat, the runs, loss of smell or sense, skin rash, or staining of fingers or toes. The manifestations experienced are generally mellow and show up step by step. A few people become contaminated but just have mellow side effects.

Most (around 80\%) tainted individuals recuperate without the requirement for unique treatment. Around 1 of every five individuals tainted with COVID-19 experience the ill effects of serious torment and trouble relaxing. Older individuals and individuals with going with comorbidity, for example, hypertension, heart and lung issue, diabetes, or malignant growth are bound to encounter progressively ailment (Yang, et.al, 2020). In any case, anybody can be contaminated with COVID-19 and experience genuine ailment. Individuals of any age who experience fever and/or hack joined by trouble breathing/brevity of breath, chest torment/weight, or loss of capacity to talk or move ought to promptly look for clinical assistance. On the off chance that conceivable, it is fitting to contact a human services supplier or wellbeing office first, so patients can be coordinated to the correct wellbeing office.

Indonesia did not have a reasonable, foreordained specialized plan for such a more awful disaster. This is the table obvious of the all-out COVID-19 contaminations on the 28th of May 2020.

Table 1. Total COVID-19 Infections on 10/06/2020

\begin{tabular}{|c|c|c|c|c|}
\hline No & & $\begin{array}{l}\text { Countr } \\
\text { ies }\end{array}$ & $\begin{array}{l}\text { Contaminate } \\
\text { d }\end{array}$ & Died \\
\hline \multirow[t]{2}{*}{1} & Global & 216 & 7.094 .473 & 406.461 \\
\hline & & Positive & Recovered & Died \\
\hline 2 & Indonesia & 34.316 & 12.129 & 1.959 \\
\hline
\end{tabular}

Source: World Health Organization \& https://covid19.go.id

\section{Natural Tourism Destination}

Regularly the travel industry goal trustworthy travel to basic zones, which 
Enggrit Novialita Kelana Sari and Carrolus Prima Ferri Karma: The Impact of COVID-19

Pandemic on Natural Tourism Destinations Managers in Samigaluh Kulon Progo District as a Nature Tourism Area

directs the earth and improves the administration help of neighbourhood people. It is the movement business reliant on the normal attractions of a zone. Models join birdwatching, photography, stargazing, outside, climbing, pursuing, calculating, and visiting parks. These experiential vacationers are excited about a conventional assortment of standard and social resources. They need what is veritable, and they should be lowered in a rich normal, social, or chronicled understanding. Outside, one of the various activities that can be acknowledged as a nature vacationer.

From the perspective of safeguarding, nature-based the movement business offers sparks to close by systems and landowners to screen untamed life domains whereupon the business depends - it progresses security by setting an extended a motivator on remaining normal zones. As nature the movement business ends up being dynamically basic to the close by the economy, systems have additional propelling power to protect their remaining ordinary zones for untamed life and normal life darlings.

\section{RESEARCH METHOD}

According to Herdiansyah (2010), subjective exploration has the pith to comprehend. Comprehend who implied is getting 'something' that can imply numerous things, for instance understanding what is seen by others, getting outlook and another person's perspective, comprehend something marvels dependent on bunch perspectives certain individuals or networks with settings common which means research must be done straightforwardly at the area of the wonder happened. Subjective exploration means to get a general comprehension of social reality from the point of view member. This comprehension is not resolved first, however, will show up after direct an examination of social reality which turned into the focal point of exploration.

Utilization of subjective strategies legitimization begins from the objective exploration that needs to dissect
(Jarzabkowski \& Kaplan, 2015) the circumstance of the directors of vacation spots in Samigaluh, just as the chance of conceivable outcomes that happen in their professions. Information assortment methods utilized is perception and meeting profound. Information downloaded the assortment of techniques of this investigation were begun by giving the poll, requesting that the members fill.

In the last survey, the scientist accumulated the poll that has been replied. The technique is impacted by Cam and Tran (2017). After the information has been gathered, it will be examined and perceived. Cam and Tran (2017) expressed that the survey is a very helpful assortment technique since scientists can arrive at numerous members and respondents in a brief timeframe and it needn't bother with cost to such an extent.

As the point of this examination was to investigate or explore Indonesian the travel industry worker's viewpoints, twelve inquiries were arranged and posed to each exploration bunch in detail. In the travel industry representative's points of view were;

1. Do you think the government does an excellent job of supporting employees in tourism and hospitality?

2. Is the operational system in your workplace still operating as usual?

3. What is the condition of your workplace?

4. If the company's operating system is still running as usual, is there a program or procedure carried out by the company in protecting visitors who are still coming?

5. The spread of the coronavirus makes the company need to make some adjustments with the main focus on protecting employees. Has your company or workplace issued a specialized policy to deal with the coronavirus?

6. If yes, then what are the specific policies that have been implemented in your workplace?

7. Do older employees in your industry (workplace) feel more concerned than younger employees? 
Enggrit Novialita Kelana Sari and Carrolus Prima Ferri Karma: The Impact of COVID-19

Pandemic on Natural Tourism Destinations Managers in Samigaluh Kulon Progo District as a Nature Tourism Area

8. Are you relaxing at home or keep working at the office?

9. The company's financial performance is currently experiencing many challenges in dealing with the coronavirus?

10. Are the wages or salaries you received during this pandemic stable?

11. Are there any employees in the company affected by layoffs or get fired because of the COVID-19 pandemic?

12. Has the workplace and you individually experienced a significant impact in this COVID-19 pandemic situations?

Additionally, those inquiries were arranged and posed to the fifty-two Indonesian travel industry representatives are the members of this examination. To examine the Indonesian the travel industry workers, so as to accomplish the objectives and targets of the examination. Concerning this examination strategy, the creators made the accompanying advances:

The arrangement of this study consists of:

1. Research Subject

The research subjects were Samigaluh tourism managers, in Indonesia with thirty people.

2. Research Place

The study was conducted in Samigaluh.

3. Research Time

This research was conducted in the 2019/2020 year.

The questionnaire which given is in English language, although some explanation that respondents addressed are in Indonesian. Despite the fact that it doesn't affect the exploration.

Additionally, they could communicate their inclination effectively and free. The poll doesn't let the respondents compose their genuine name. They also could compose sex. At that point, the specialist will name them as respondent one, two, etc. and it doesn't affect the information that has gathered.
RESULT AND DISCUSSION

Table 2. The Tourist Attractions Affected by COVID-19 in Samigaluh

\begin{tabular}{cl}
\hline No & \multicolumn{1}{c}{ Tourism Attractions } \\
\hline 1 & Pringtali Temple \\
\hline 2 & Suroloyo Peak \\
\hline 3 & Kendil Hill \\
\hline 4 & Isis Hill \\
\hline 5 & Nglinggo Tea Garden \\
\hline 6 & Jaran Hill \\
\hline 7 & Jonggol Waterfall \\
\hline 8 & Tritis Tea Garden \\
\hline 9 & Widosari Peak \\
\hline 10 & Sidoharjo Waterfall \\
\hline 11 & Kleco Hill \\
\hline 12 & Sriti Cave \\
\hline 13 & Watu Tekek Hill \\
\hline 14 & Chrysanthemum Agrotourism \\
\hline 15 & Tinalah Tourism Village \\
\hline
\end{tabular}

As for the tourist attractions affected by Covid-19 in Samigaluh that has been explained in Table 3. In the table above it is clearly shown that almost all tourist attractions in Samigaluh are affected. Affected here means that there is a temporary closure or a reduction in tourist visits by tourists in the places mentioned above.

Table 3. Gender of Respondents

\begin{tabular}{cccc}
\hline No & Variable & Gender & Sample \% \\
\hline 1 & Gender & Male & $73,4 \%$ \\
\hline 2 & & Female & $26,6 \%$ \\
\hline
\end{tabular}

The overall gender of respondents, it appears that there there are many individuals who filled the survey. It clearly appears on the table that male gender is over $73.4 \%$ or 212 individuals, and the female gender who have filled the questionnaires are over $26.6 \%$ or 8 . It expressly appears that the male gender has higher recurrence by filling the surveys instead of the male one. Male enlisted the biggest number of respondents. 
Enggrit Novialita Kelana Sari and Carrolus Prima Ferri Karma: The Impact of COVID-19

Pandemic on Natural Tourism Destinations Managers in Samigaluh Kulon Progo District as a Nature Tourism Area

\section{Table 4. The Effect of Covid-19 Pandemic on Tourism Destination's Managers in Samigaluh Kulon Progo District as a Nature Tourism Area}

\begin{tabular}{|c|c|c|}
\hline Question & \multicolumn{2}{|c|}{$\begin{array}{l}\text { Respondents } \\
\text { Answers (\%) }\end{array}$} \\
\hline $\begin{array}{l}\text { Do you think the government } \\
\text { does an excellent job of } \\
\text { supporting employees in } \\
\text { tourism and hospitality? }\end{array}$ & $46.6 \%$ & $53.4 \%$ \\
\hline $\begin{array}{l}\text { Is the operational system in } \\
\text { your workplace still operating } \\
\text { as usual? }\end{array}$ & $46.6 \%$ & $53.4 \%$ \\
\hline $\begin{array}{l}\text { What is the condition of your } \\
\text { workplace? }\end{array}$ & $\begin{array}{r}\text { Brief } \\
\text { Answers }\end{array}$ & $\begin{array}{r}\text { Brief } \\
\text { Answer }\end{array}$ \\
\hline $\begin{array}{l}\text { If the company's operating } \\
\text { system is still running as usual, } \\
\text { is there a program or procedure } \\
\text { carried out by the company in } \\
\text { protecting visitors who are still } \\
\text { coming? }\end{array}$ & $\begin{array}{r}\text { Brief } \\
\text { Answers }\end{array}$ & $\begin{array}{r}\text { Brief } \\
\text { Answer } \\
\mathrm{s}\end{array}$ \\
\hline $\begin{array}{l}\text { The spread of the coronavirus } \\
\text { makes the company need to } \\
\text { make some adjustments with } \\
\text { the main focus on protecting } \\
\text { employees. Has your company } \\
\text { or workplace issued a } \\
\text { specialized policy to deal with } \\
\text { the coronavirus? }\end{array}$ & $76.6 \%$ & $23.4 \%$ \\
\hline $\begin{array}{l}\text { If yes, then what are the } \\
\text { specific policies that have been } \\
\text { implemented in your } \\
\text { workplace? }\end{array}$ & $\begin{array}{r}\text { Brief } \\
\text { Answers }\end{array}$ & $\begin{array}{r}\text { Brief } \\
\text { Answer } \\
\mathrm{s}\end{array}$ \\
\hline $\begin{array}{l}\text { Do older employees in your } \\
\text { industry (workplace) feel more } \\
\text { concerned than younger } \\
\text { employees? }\end{array}$ & $83.4 \%$ & $25 \%$ \\
\hline $\begin{array}{l}\text { Are you laid off at home or } \\
\text { keep working at the office? }\end{array}$ & $86.7 \%$ & $13.3 \%$ \\
\hline $\begin{array}{l}\text { The company's financial } \\
\text { performance is currently } \\
\text { experiencing many challenges } \\
\text { in dealing with the } \\
\text { coronavirus? }\end{array}$ & $10 \%$ & $90 \%$ \\
\hline $\begin{array}{l}\text { Are the wages or salaries you } \\
\text { received during this pandemic } \\
\text { stable? }\end{array}$ & $43.4 \%$ & $56.6 \%$ \\
\hline $\begin{array}{l}\text { Are there any employees in the } \\
\text { company affected by layoffs or } \\
\text { get fired because of the } \\
\text { COVID-19 pandemic? }\end{array}$ & $38.5 \%$ & $61.5 \%$ \\
\hline
\end{tabular}

\begin{tabular}{lcc}
\hline \multicolumn{1}{c}{ Question } & \multicolumn{2}{c}{$\begin{array}{c}\text { Respondents' } \\
\text { Answers (\%) }\end{array}$} \\
\hline $\begin{array}{l}\text { Has the workplace and you } \\
\text { individually experienced a } \\
\text { significant impact in this }\end{array}$ & $90 \%$ & $10 \%$ \\
COVID-19 pandemic \\
situations?
\end{tabular}

Based on Table 4 has distinguished about the level of the travel industry emergency and its effects of Indonesian travel industry representatives' viewpoints in the pandemic of COVID-19. The analyst has spread twelve inquiries for being filled by the respondents.

First, the inquiry is whether the administration works admirably of supporting representatives in the travel industry and cordiality or not.

Second, the inquiry is whether the operational framework in your work environment despite everything working as common or not.

Third, the inquiry is really posing to them to offer brief response the inquiry is "provided that this is true, what is the state of your work environment". Along these lines, every respondent needs to expand their answer in a nutshell about the state of their work environment in the event that they are as yet working in the workplace.

Fourth, the inquiry is whether the organization's working framework is as yet running obviously, is there any program or methodology did by the organization in securing guests who are as yet coming.

Fifth, the inquiry is about the spread of the coronavirus makes the organization need to make a few changes with the primary spotlight on ensuring representatives. Has the organization or working environment gave a particular strategy to manage the coronavirus or not. In this way, the following inquiry is just supporting the past inquiry.

Sixth, the respondent needs to expand their answer in a nutshell "On the off chance that truly, at that point what are the particular arrangements that have been executed in your work environment?" the respondent can expound the appropriate response quickly. 
Enggrit Novialita Kelana Sari and Carrolus Prima Ferri Karma: The Impact of COVID-19

Pandemic on Natural Tourism Destinations Managers in Samigaluh Kulon Progo District as a Nature Tourism Area

Seventh, the inquiry is whether the more seasoned representatives in the business (working environment) feel more worried than more youthful representatives or not.

Eighth, the inquiry is whether the representatives telecommute or not.

Ninth, the inquiry is "Are there any representatives in the organization influenced by cutbacks or terminated as a result of the COVID-19 pandemic?". Next, the inquiry is "Has the working environment, and you separately encountered a critical effect in this COVID-19 pandemic circumstances?". Last, the inquiry is actually just supporting the past inquiry which the respondent can expand their answer in a word, expound the appropriate response about the effects on the specialist itself and what occurred in the work environment in this COVID-19 pandemic circumstance.

This part comprises the exploration results and how they are talked about. The outcomes got from the exploration must be upheld by adequate information above. The table 3 shows that twelve inquiries being shared to the respondents to be satisfied. Initially, when the respondents were asked whether the legislature works superbly of supporting representatives in the travel industry and neighbourliness or not, the outline shows that $46.6 \%$ or 14 respondents concurred with this on the grounds that the administration does a really great job of supporting workers in the travel industry and friendliness. Other than it, there are a couple of respondents who don't concur; the chart shows that $53.4 \%$ or 16 respondents didn't concur with this. It obviously shows that we can see there are some travel industry goals are not being upheld truly well by the legislature yet. Also, when the respondents were asked whether the operating system in the work environment despite everything working as common or not, the outline shows that $46.61 \%$ or 14 respondents concurred with this.

In addition, there are barely any respondents don't concur; the chart shows that $53.4 \%$ or 16 respondents didn't concur with this. We can see it unmistakably that the huge number of the respondents during the current second inquiry, the majority of them don't concur. In any case, there are scarcely any respondents concur and differ which they were contended about the inquiries and have variations sees. Respondent 11 says "not working as of now, particularly the complete crown cases taking off to about 20,000 individuals, and PSBB (Pembatasan Sosial Berskala Besar) or in English, it is called as Huge scope social limitations will likewise be expanded, so the work environment isn't working."

In addition, in the fourth inquiry that has been spread to the respondents, which inquired as to whether the organization's working framework is as yet running, not surprisingly, is there a program or strategy completed by the organization in securing guests who are as yet coming. In the end, the greater part of the respondents has comparative reactions. For example, the respondent 22 says "Yes there is, t], and there is an alert as banners or flyers eventually as data about the anticipation of COVID-19 and clean living conduct, at that point hand sanitizers are given, disinfectants and do the wellbeing convention".

Additionally, respondent 2 says "Giving hand sanitizers, before entering the vacationer goal, you should check your internal heat level and should wear a veil and do physical separating". The greater part of the respondents are concurred with the question and have comparable reactions and points of view.

In this manner, the fifth inquiry posed about the spread of the coronavirus makes the organization need to make a few changes with the primary spotlight on ensuring representatives. Has the organization or working environment gave have a particular approach to manage the coronavirus or not. The chart shows that $76.6 \%$ or 23 respondents concurred with this, and $23.4 \%$ or seven respondents can't help contradicting this one. A few respondents concur about this. The respondent 8 says "The representatives 
Enggrit Novialita Kelana Sari and Carrolus Prima Ferri Karma: The Impact of COVID-19

Pandemic on Natural Tourism Destinations Managers in Samigaluh Kulon Progo District as a Nature Tourism Area

telecommute, we every so often come to work to do picket yet apply physical removing and look after tidiness", and the respondent 26 says "With the expansion in coronavirus cases in Indonesia, the organization requested that representatives pause and be sent home until the coronavirus and the pandemic circumstance improve".

Afterwards, the seventh inquiry posed about whether the more established representatives in your industry (working environment) feel more worried than more youthful representatives or not. The outline shows that $83.4 \%$ or 25 respondents concurred with this, and $16.6 \%$ or five respondents can't help contradicting this one. At that point, the inquiry eight were posed about whether the representative's work from home or not. The outline shows that $86.7 \%$ or 26 respondents accomplish telecommute, and $13.3 \%$ or four respondents are as yet working at the working environment or office. Besides, the ninth inquiry was posed about the organization's money related execution is as of now encountering numerous difficulties in managing the coronavirus.

The wages or pay rates of representatives got during this pandemic is steady or not. The outline shows that $10 \%$ or three respondents say yes regarding this, and $90 \%$ or 27 respondents state no. It obviously shows that a large portion of the Indonesian the travel industry representatives are not steady in getting wages or pay rates. At that point, in this pandemic of COVID-19, there are bounty issues which are occurring like the end of the business, similar to Indonesian representatives land terminated from the position. It identified with one of the inquiries given to the respondents by the scientist.

The inquiry ten was posed about there are any workers in the organization influenced by cutbacks or terminated due to the COVID19 pandemic or not. The outline shows that $43.4 \%$ or 13 respondents say yes regarding this and $56.6 \%$ or 19 respondents state no, which implies it obviously expressed that the greater part of the representatives despite everything working and have not to get terminated. In spite of, there is a respondent conveyed the appropriate response among this inquiry. Respondent 14 says "The number of lodging representatives laid off or get terminated, for example, office kid or cleaner, the organization terminated the workers on the grounds that there is no pay to pay representatives, then again, the organization is additionally required to make good on charges. The organization's pay dropped significantly from before the PSBB (Pembatasan Sosial Berskala Besar) or in English it is called as a Largescale social limitations strategy was executed in Indonesia. In the event that the PSBB (Pembatasan Sosial Berskala Besar) is as yet actualized, the organization (inn) will absolutely encounter insolvency/out of different professional inns.", the respondent 47 have alternate points of view of the appropriate response, respondent 47 says "Diminishing pay for the representatives and organizations, there are some who are laid off or get terminated, for example, easygoing representatives, so the individuals who are as yet working are lasting representatives". It has been greats issue nowadays while pandemic of COVID-19 which there are critical quantities of representatives get terminated from the business. Besides, the aftereffect of the respondent shows $46.2 \%$ or 24 the Indonesian travel industry representatives get terminated from the business, and the rest don't get terminated from the business.

In closing, the last inquiry that given to the respondents about the working environment and the representative exclusively encountered a huge effect in this COVID-19 pandemic circumstances or not. The chart shows that $90 \%$ or 27 respondents say yes regarding this and $10 \%$ or three respondents state no, which implies it obviously expressed that the greater part of the directors encountered a noteworthy effect in this pandemic of COVID-19 circumstances. The short answer has composed by respondent 13 who is one of the directors at Nglinggo Tea Garden expressed "The quantity of visitors is exceptionally abandoned particularly on the 
Enggrit Novialita Kelana Sari and Carrolus Prima Ferri Karma: The Impact of COVID-19

Pandemic on Natural Tourism Destinations Managers in Samigaluh Kulon Progo District as a Nature Tourism Area

grounds that Yogyakarta Train station is shut and the impediment of guests in Special Region of Yogyakarta." Meanwhile, respondent 20 is one of the chiefs of Sidoharjo Waterfall expressed that "There are practically no guests come here on account of this pandemic."

This investigation shows that every travel industry goals has it possesses points of view of their concern and how to deal with their travel industry goal and administrators, and apparently their assessment on how well the business prop the business up and furthermore the chiefs. In this manner, from the clarification and table over the job of Indonesian government does an entirely great job of supporting workers (supervisors) in the domain of the travel industry and friendliness.

\section{CONCLUSION}

Overall, the current study investigated the Samigaluh tourism and hospitality manager's perspectives in the pandemic of COVID-19. This research shed further insight on the tourism sector or industry in Samigaluh, which recently experienced a disastrous condition as Tourism and Hospitality Business suspended all their operational activities from and to Indonesia due to the outbreak of COVID-19. Consequently, travel, restaurant, resort, hotel, wedding consultant, medical evacuation in the transportation industry also going through a challenging and tough time as all of the respondents are imposed and delivered their perspectives. This paper also highlighted the virus outbreak and its impact on the tourism destinations industry. Presently, this unprecedented tourism crisis and its impacts have been a devastating economic disaster for the planet as a whole and, as a result, tourism hospitality and also the event sector. The rehabilitation must be phased in parallel with the recovery of other sectors, the fight against the epidemic and the rehabilitation of economic performance. The necessary steps are to be introduced exponentially in reaction to the evolving conditions. Therefore, ensuring the safety of the guests and the staff have become a top concern of the tourism and hospitality industry stakeholders. At the same time, in order to restore business losses and to rebuild a favourable picture in the eyes of the customers, it is necessary that good marketing is undertaken and promotional campaigns, both locally and internationally.

\section{REFERENCES}

Cam, L., \& Tran, T. M. T. (2017). An evaluation of using games in teaching English grammar for first year Englishmajored students at Dong Nai Technology University. International Journal of Learning, Teaching and Educational Research, 16(7), 55-71.

Herdiansyah, Haris. 2010. Metode Penelitian Kualitatif untuk Ilmu-ilmu Sosial. Jakarta: Salemba Humanika

Jaelani, A. (2017). Halal tourism industry in Indonesia: Potential and prospects. International Review of management and Marketing, 7(3).

Jarzabkowski, P., \& Kaplan, S. (2015). Strategy tools-in-use: A framework for understanding "technologies of rationality" in practice. Strategic management journal, 36(4), 537-558.

Mandal, I., \& Pal, S. (2020). COVID-19 pandemic persuaded lockdown effects on environment over stone quarrying and crushing areas. Science of The Total Environment, 732, 139281.

Ramteke, S., \& Sahu, B. L. (2020). Novel coronavirus disease 2019 (COVID-19) pandemic: considerations for the biomedical waste sector in India. Case Studies in Chemical and Environmental Engineering, 100029.

World Health Organization. (2020). Coronavirus disease 2019 (COVID-19): situation report, 85 .

Yang, J., Zheng, Y., Gou, X., Pu, K., Chen, Z., Guo, Q., ... \& Zhou, Y. (2020). Prevalence of comorbidities in the novel Wuhan coronavirus (COVID-19) infection: a systematic review and metaanalysis. International journal of infectious diseases. 
Enggrit Novialita Kelana Sari and Carrolus Prima Ferri Karma: The Impact of COVID-19 Pandemic on Natural Tourism Destinations Managers in Samigaluh Kulon Progo District as a Nature Tourism Area

Zahra, F., Gul, A., Iqbal, A., Ghafoor, T., \& Ambreen, A. (2020). The Impact of Covid-19 on Rural Areas Students of Pakistan: Moderating Role of HEC Policy and Internet Service. Asian Journal of Contemporary Education, 4(2), 69-79.

Zhu, L., Xu, X., Ma, K. E., Yang, J., Guan, H., Chen, S., ... \& Chen, G. (2020). Successful recovery of COVID-19 pneumonia in a renal transplant recipient with long-term immunosuppression. American Journal of Transplantation. 